\title{
Quinoxaline-based small molecules: synthesis and investigation on their optoelectronic properties
}

\author{
Jiyong Deng*, Qiang TaO, Dong Yan, Xianwei Huang, Yunfeng Liao \\ School of Chemistry and Chemical Engineering, Hunan Institute of Engineering, Xiangtan, Hunan, China
}

\begin{abstract}
Small molecules of ThQuTh, CzQuTh, CzQuCz and TPAQuCz were designed and synthesized, based on quinoxaline acceptor, and electron donating groups, i.e. alkyl-thioephene, carbazole and triphenylamine on both side chains and molecular backbones. Their thermal, optical and electrochemical properties were systematically compared and studied. The absorption spectra of the small molecules were strongly affected by the donor units attached to quinoxaline. Strong electron donating groups, such as carbazole on the molecular backbone would lower optical band gap, resulting in a wide absorption and the strong donor on the side chain would enhance the absorption intensity in short wavelength region. The highest occupied molecular orbital (HOMO) energy levels of the four molecules were up-shifted with increasing the electron donating properties of donor units. The bulk-heterojunction organic solar cells with a device structure of ITO/PEDOT:PSS/SMs:PC 61 BM/LiF/Al were fabricated, in which the small molecules functioned as donors while $\mathrm{PC}_{61} \mathrm{BM}$ as acceptor. Because the electron-donating ability of carbazole (Cz), triphenylamine (TPA) is higher than that of thiophene (Th), CzQuTh, CzQuCz and TPAQuCz show higher power conversion efficiency (PCE) than that of ThQuTh. Furthermore, being the strongest in absorption intensity and widest in absorption spectrum, TPAQuCz has the highest power conversion efficiency. Further improvement of the device efficiency by optimizing the device structure is currently under investigation.
\end{abstract}

Keywords: quinoxaline; acceptor materials; optoelectronic properties; solar cells

\section{Introduction}

The foreseeable exhaustion of fossil fuels stimulates the pursuit of renewable energy. Harvesting solar energy by photovoltaic means has attracted enormous attention. Bulk heterojunction organic solar cells (BHJ-OSCs) including polymer solar cells (PSCs) and small molecules solar cells (SMSs) were studied. With the use of polymer donors and fullerene acceptors, the power conversion efficiencies (PCEs) of PSCs were improved dramatically in the last decade [1-8], reaching the highest value of $11.7 \%$ [9]. Nonetheless, there are disadvantages with PSCs, such as unreliable batch-to-batch performance, high purity demand of ingredients, and poor controllability of polymer molecular weight $[10,11]$. In contrast, the use of small molecules (SMs) for the fabrication of BHJ-OSCs is favorable because of well-defined structures, which are mono-dispersive, simple

*E-mail: djyong@yeah.net to synthesize and easy to purify. They are highly mobile and have no end-group contaminants. Consequently, the use of SMs as charge carriers for BHJ-OSCs fabrication enables reliable batchto-batch performance [12-16]. The highest PCE achieved so far for solution-processed SMs-based BHJ-OSCs is $10.01 \%$ [15], somewhat lower than that of PSCs [17].

For the improvement of power conversion efficiency in BHJ-OSCs applications, SMs with low band gap, broad and strong solar light absorption, and high charge-carrier mobility are desired [18, 19]. Various strategies were developed to generate SMs of this kind. A popular approach is to synthesize SMs with alternating donor D and acceptor $\mathrm{A}$ monomer units. Among the D-A materials, the starshaped ones, large in structure and purposely decorated with electron-donating groups are known to be mono-dispersive and highly soluble in organic solvents [20,21].

With low band gap and being efficient for electron injection and transport, benzo-quinoxaline 


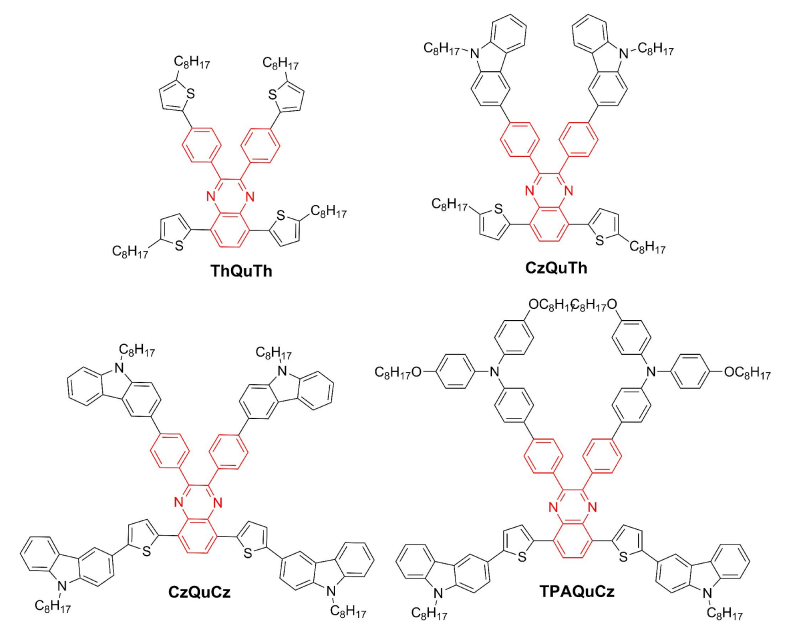

Fig. 1. Molecular structures of quinoxaline based SMs.

derivatives are used as acceptor units in polymer photovoltaic cells [22-25]. However, the quinoxaline moiety based small molecules have been reported rarely because of their low PCEs in solar cells. Additionally, the morphological investigations demonstrated that the low PCEs of quinoxaline moiety based small molecules were mainly due to the inappropriate phase segregation and limited light harvesting of the donor blends [26-28]. To further explore the potential of SMs as donor materials in organic solar cells, we report in this work, the design and synthesis of a series of star-shaped $\mathrm{D}-\mathrm{A}$ molecules using benzo-quinoxaline as a core, by extending the $\pi$-conjugation, enhancing the solubility and intramolecular interactions (Fig. 1). With high electron affinity, benzo-quinoxaline is a good electron acceptor and the use of it can generate SMs with low band gaps. We attached thiophene (Th), carbazole $(\mathrm{Cz})$ and triphenylamine (TPA) group to the core. The TPA and $\mathrm{Cz}$ groups are known to have good optical properties and hole transporting ability. Furthermore, the TPA unit is a three-dimensional propeller structure, and its presence promotes the amorphous nature and solution processability of the corresponding SMs. This kind of compounds has many innovative characteristics: (1) dipolarity due to charge transfer from electrondonating groups to the quinoxaline core and red shift of electronic absorption band [29]; (2) reduction of band gap due to internal charge transfer; and
(3) tuning of energy levels by adjusting the degree of intramolecular charge transfer through the introduction of different electron-donating moieties to the electron-withdrawing moiety.

In the present study, we investigated the photophysical, thermal, electrochemical and photovoltaic properties of the synthesized SMs. Furthermore, the nature of the BHJ-OSCs with the device structure of ITO/PEDOT:PSS/small molecule $\mathrm{PC}_{60} \mathrm{BM} / \mathrm{LiF} / \mathrm{Al}$ was investigated. As envisaged, the benzo-quinoxaline core plays a positive role for the promotion of power conversion across the solar cells. What is more, the results demonstrate that by increasing the electron-donating ability of the D moiety, widening of absorption spectrum, improvement of thermal stability as well as enhanced photovoltaic performance can be achieved.

\section{Experimental}

\subsection{Materials}

All reagents and chemicals were purchased from commercial sources (Aldrich, Acros, TCI) and used without further purification unless stated otherwise. Tetrahydrofuran (THF) was distilled over sodium and benzophenone under an inert nitrogen atmosphere.

\subsection{Instrumentation and measurements}

Column chromatography was carried out with Merck silica gel (200 to 300 mesh). The NMR spectra were collected on a Bruker DPX $400 \mathrm{spec}-$ trometer using chloroform-d as a solvent and tetramethylsilane (TMS) as internal standard. Thermogravimetric analysis (TGA) was carried out using a Netzsch TG 209 analyzer at a heating rate of $10{ }^{\circ} \mathrm{C} \min ^{-1}$ up to $600{ }^{\circ} \mathrm{C}$. UV-Vis absorption spectra were recorded on a PerkinElmer Lambda 25 spectrometer. Cyclic voltammograms $(\mathrm{CV})$ of the molecules were recorded on a CHI 660 electrochemical workstation at a scanning rate of $100 \mathrm{mV} \cdot \mathrm{s}^{-1}$. Their measurements were carried out at room temperature using a three-electrode setup with two platinum electrodes for both the working electrode and counter 
electrode. $\mathrm{Ag} / \mathrm{AgCl}$ was used as the reference electrode in an anhydrous acetonitrile solution with 0.1 $\mathrm{M}$ nitrogen-saturated tetrabutylammonium hexafluorophosphate $\left(\mathrm{Bu}_{4} \mathrm{NPF}_{6}\right)$ calibrated with a ferrocene/ferrocenyl couple $\left(\mathrm{Fc} / \mathrm{Fc}^{+}\right)$. The $\mathrm{HOMO}$, LUMO energy levels ( $\mathrm{E}_{\mathrm{HOMO}}$ and $\mathrm{E}_{\text {LUMO }}$ ) and electrochemical band gaps $\mathrm{E}_{\mathrm{g}}^{\mathrm{ec}}$ were calculated by the following equations:

$$
\begin{aligned}
& E_{\text {НОмо }}=-\left(E_{\text {ox }}+4.80\right) \mathrm{eV} \\
& E_{L U M O}=-\left(E_{\text {HOMO }}+E_{g}^{o p t}\right)
\end{aligned}
$$

\subsection{Solar cells fabrication and character- ization}

A traditional sandwich structure was used in the solar cell fabrication. The ITO/glass substrates were ultrasonic-cleaned by detergent, deionizer water, acetone and isopropanol for $15 \mathrm{~min}$ each in sequence. The resulting substrates were dried under a stream of nitrogen and subjected to the treatment of $\mathrm{Ar} / \mathrm{O}_{2}$ plasma for $5 \mathrm{~min}$. A layer of $30 \mathrm{~nm}$ of poly(3,4-ethylenedioxythiophene)poly(styrenesulfonate) (PEDOT-PSS) film was spin-coated on ITO and then the substrates were baked at $140{ }^{\circ} \mathrm{C}$ for $10 \mathrm{~min}$ in a glove box. A blend solution of donor materials and $[6,6]-$ phenyl-C-61-butyric acid methyl ester $\left(\mathrm{PC}_{61} \mathrm{BM}\right)$ in chloroform were then spun cast onto the PEDOT:PSS layer. The substrates were dried under $\mathrm{N}_{2}$ atmosphere at room temperature and then annealed at $150{ }^{\circ} \mathrm{C}$ for $15 \mathrm{~min}$ in a nitrogen-filled glove-box. Finally, $10 \mathrm{~nm}$ calcium and $100 \mathrm{~nm}$ aluminum films were deposited on the active layer under vacuum. The film thickness of the active layers was around $100 \mathrm{~nm}$ and active area was $0.1 \mathrm{~cm}^{2}$ for each cell. The efficiency of a solar cell was evaluated under AM 1.5G irradiation of $100 \mathrm{~mW} \cdot \mathrm{cm}^{-2}$ intensity (Oriel 91160, 300 W) calibrated by a NREL-certified standard silicon cell. Current density-voltage (J-V) characteristics were examined in the dark using a computercontrolled Keithley 2602 source measurement unit. The cell was placed under monochromatic illumination (Oriel Cornerstone 260 1/4 m monochromator equipped with Oriel 70613NS QTH lamp) and the incident light was calibrated with a monocrystalline silicon diode. All characterizations were performed under ambient conditions.

\subsection{Synthesis}

Compounds of 5-octyl-2-(tributylstannyl)thiophene (1) [29], 4,7-bis(5-octylthiophen-2yl)benzo[c][1,2,5] thiadiazole (2) [30], 4,7-bis(5bromo-2-thienyl)-2,1,3-benzothiadiazole (4) [31], 1-(4-(9-octyl-9H-carbazol-3-yl)phenyl)-2-(4-(9octyl-9H-carbazol-6-yl)phenyl)ethane-1,2-dione (8) [32], and N,N-bis((4-octyloxyl)phenyl)-N-(4(4,4,5,5-tetramethyl-1,3,2-dioxa-borolan-2-yl)phenyl)benzenamine (9) [33] were synthesized according to the procedures in the literature. The synthetic routes are presented in Fig. 2.

\section{5-octyl-2-(tributylstannyl)-thiophene (1)}

A solution of $\mathrm{n}-\mathrm{BuLi}(12 \mathrm{~mL}, 0.03 \mathrm{~mol}$, in $2.5 \mathrm{M}$ hexane) was added dropwise over a period of $1 \mathrm{~h}$ to a stirred solution of 2-n-octylthiophene (4.6 g, $0.023 \mathrm{~mol}$ ) in $120 \mathrm{~mL}$ THF at $-78{ }^{\circ} \mathrm{C}$. The mixture was then stirred for another $2 \mathrm{~h}$ at $-78{ }^{\circ} \mathrm{C}$ before chlorotributyltin $(11 \mathrm{~g}, 0.03 \mathrm{~mol})$ was added. The resulting mixture was stirred for $30 \mathrm{~min}$ and left under stirring at room temperature for $24 \mathrm{~h}$. The reaction mixture was poured into $200 \mathrm{~mL}$ of water and extracted with ether. The combined organic phase was washed with brine, dried over anhydrous sodium sulfate $\left(\mathrm{MgSO}_{4}\right)$, and subjected to decompression evaporation to remove excess chlorotributyltin to afford the product as a yellow oil (9.2 g, yield: 94.2\%). ${ }^{1} \mathrm{H}$ NMR $\left(400 \mathrm{MHz}, \mathrm{CDCl}_{3}, \mathrm{TMS}, \delta_{\mathrm{ppm}}\right): 7.00(\mathrm{~s}, 1 \mathrm{H}), 6.92$ (s, 1H), 2.87 (t, J = $7.60 \mathrm{~Hz}, 2 \mathrm{H}), 1.87$ to 0.68 (m, $42 \mathrm{H})$

\section{4,7-bis(5-octylthiophen-2-yl)benzo[c] $] 1,2,5]$ thiadiazole (2)}

A mixture of 4,7-dibromo-2,1,3benzothidiazole $(1 \mathrm{~g}, 3.4 \mathrm{mmol})$, compound (1) $(4.12 \mathrm{~g}, 6.8 \mathrm{mmol}), \quad \mathrm{Pd}\left(\mathrm{PPh}_{3}\right)_{4}(0.10 \mathrm{~g}$, $0.088 \mathrm{mmol}$ ) and $20 \mathrm{~mL}$ toluene was carefully degassed and charged with nitrogen. The mixture 

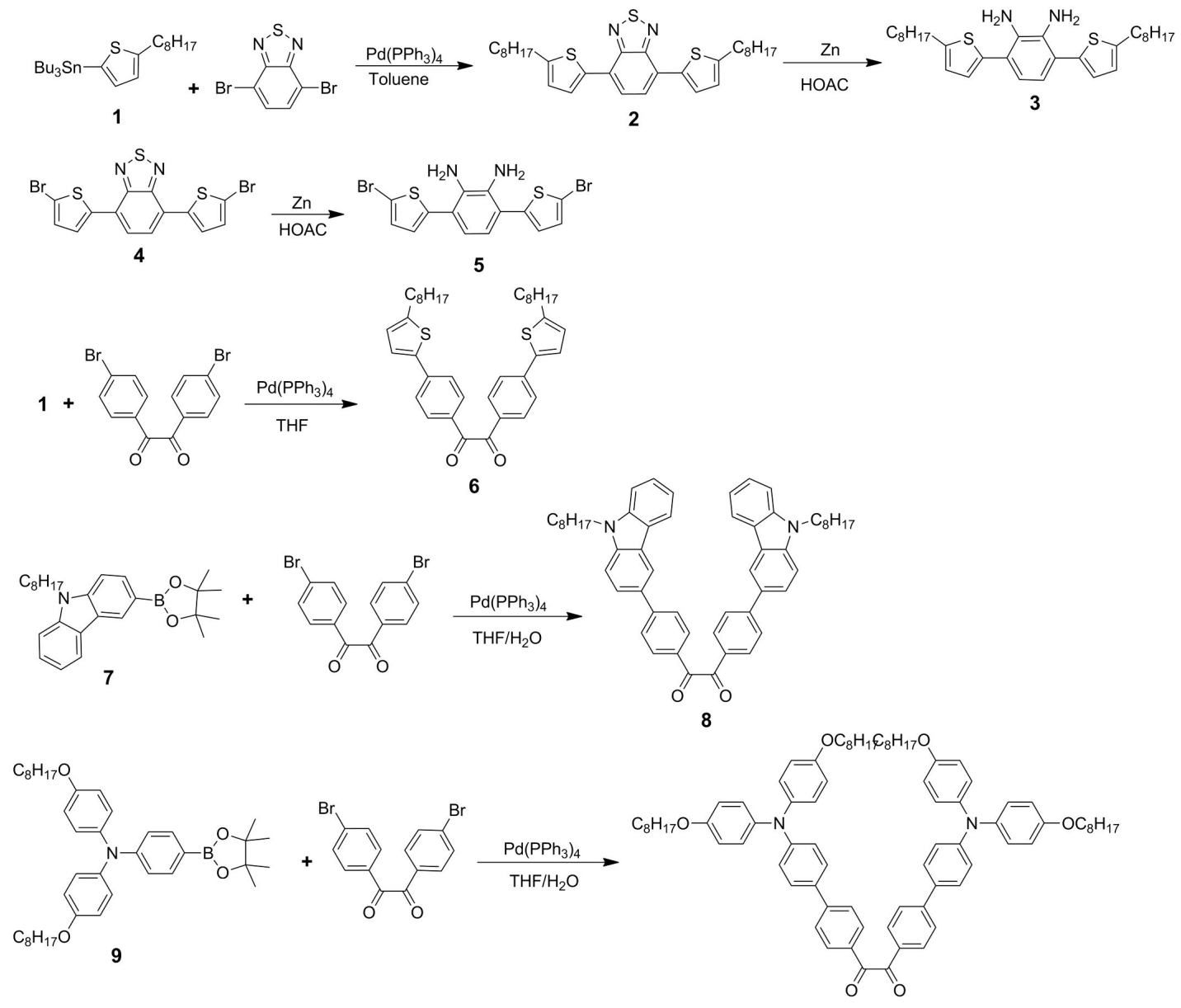

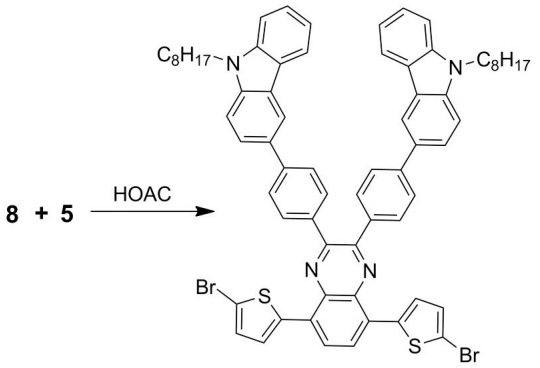

11

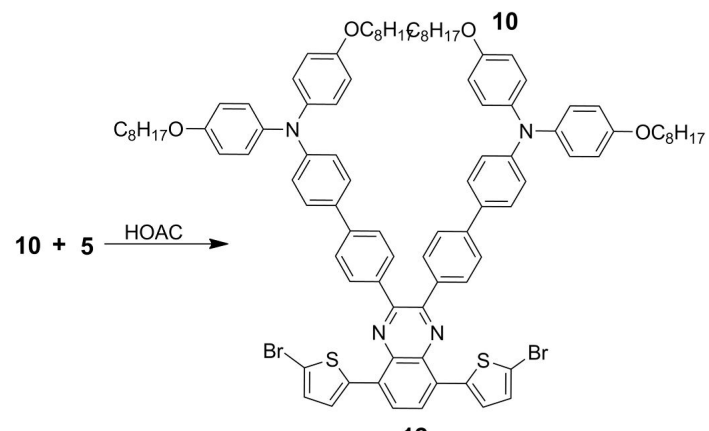

12

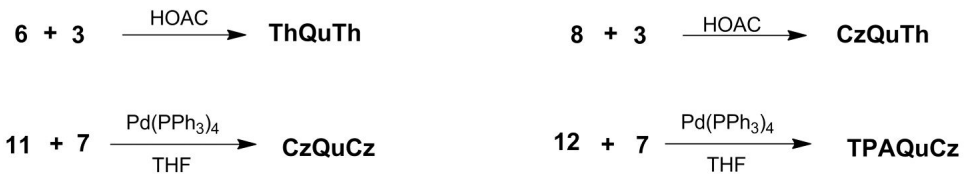

Fig. 2. The synthetic route for the four small molecules.

was then stirred for $30 \mathrm{~min}$ at $60{ }^{\circ} \mathrm{C}$ before it with chloroform. The combined organic phase was heated to reflux for $24 \mathrm{~h}$. After cooling to was washed with brine, dried over anhydrous room temperature, the mixture was extracted sodium sulfate $\left(\mathrm{MgSO}_{4}\right)$, and distillated over 
the majority of solvent. The crude was purified by column chromatography using a mixture solvent of dichloromethane and petroleum ether (1:10) as eluent to afford the product as a red purple solid (0.71 g, yield: $39.9 \%) .{ }^{1} \mathrm{H}$ NMR $(400 \mathrm{MHz}$, $\left.\mathrm{CDCl}_{3}, \mathrm{TMS}, \delta_{\mathrm{ppm}}\right): 7.96(\mathrm{~d}, \mathrm{~J}=4.0 \mathrm{~Hz}, 2 \mathrm{H})$, $7.31(\mathrm{~d}, \mathrm{~J}=5.1 \mathrm{~Hz}, 2 \mathrm{H}), 6.92(\mathrm{~d}, \mathrm{~J}=3.2 \mathrm{~Hz}, 2 \mathrm{H})$, $2.93(\mathrm{t}, \mathrm{J}=11.2 \mathrm{~Hz}, 4 \mathrm{H}), 1.83$ to $1.76(\mathrm{~m}, 4 \mathrm{H})$, 1.46 to $1.34(\mathrm{~m}, 20 \mathrm{H}), 0.92(\mathrm{~d}, \mathrm{~J}=13.6 \mathrm{~Hz}, 6 \mathrm{H})$.

\section{3,6-bis(5-octylthiophen-2-yl)benzene-1,2-dia- mine (3)}

To a solution of compound (2) (0.80 g, $1.52 \mathrm{mmol})$ in acetic acid $(40 \mathrm{~mL})$, zinc dust $(1.23 \mathrm{~g}, 18.85 \mathrm{mmol})$ was added, and the mixture was stirred at $80{ }^{\circ} \mathrm{C}$ for $2 \mathrm{~h}$ and then subjected to filtration. The as-acquired liquid was basified with $2 \mathrm{M} \mathrm{NaOH}$ and extracted three times with $100 \mathrm{~mL}$ of dichloromethane. The removal of solvent from the combined organic extracts using a rotary evaporator gave the product $(0.62 \mathrm{~g}$, yield: $84.3 \%)$ in the form of colorless oil.

\section{3,6-bis(5-bromothiophen-2-yl)benzene-1,2-dia-} mine (5)

According to a procedure similar to that of (3), compound (5) was obtained from (4) as a colorless solid with a yield of $83.1 \%$.

\section{5,8-Bis(5-bromothiophen-2-yl)-2,3-bis(4-(9-} octyl-9H-carbazol-3-yl)-phenyl)quinoxaline (11)

A suspension of compound (8) (0.45 g, $0.58 \mathrm{mmol})$ and compound (5) $(0.30 \mathrm{~g}, 0.70 \mathrm{mmol})$ in acetic acid $(18 \mathrm{~mL})$ was heated to reflux for $24 \mathrm{~h}$, during which a yellow precipitate was formed. After filtration, the residue was purified by column chromatography using a mixture of dichloromethane and petroleum ether (1:3) as eluent. The product $(0.59 \mathrm{~g}, 87.3 \%$ yield $)$ was obtained as a yellow solid. ${ }^{1} \mathrm{H}$ NMR $(400 \mathrm{MHz}$, $\left.\mathrm{CDCl}_{3}, \mathrm{TMS}, \delta_{\mathrm{ppm}}\right): 8.55(\mathrm{~s}, 2 \mathrm{H}), 8.29(\mathrm{~d}$, $\mathrm{J}=7.4 \mathrm{~Hz}, 2 \mathrm{H}), 8.22(\mathrm{~s}, 2 \mathrm{H}), 8.05(\mathrm{~d}, \mathrm{~J}=8.2 \mathrm{~Hz}$, 4H), $7.95(\mathrm{~d}, \mathrm{~J}=8.0 \mathrm{~Hz}, 6 \mathrm{H}), 7.74(\mathrm{~d}, \mathrm{~J}=3.7 \mathrm{~Hz}$,
$2 \mathrm{H}), 7.60(\mathrm{~d}, \mathrm{~J}=6.3 \mathrm{~Hz}, 4 \mathrm{H}), 7.41$ to $7.33(\mathrm{~m}$, $8 \mathrm{H}), 4.45(\mathrm{t}, \mathrm{J}=6.9 \mathrm{~Hz}, 4 \mathrm{H}), 2.03$ to $2.00(\mathrm{~m}$, $4 \mathrm{H}), 1.52$ to $1.37(\mathrm{~m}, 20 \mathrm{H}), 0.97(\mathrm{t}, \mathrm{J}=6.7 \mathrm{~Hz}, 6 \mathrm{H})$.

5,8-Bis(5-bromothiophen-2-yl)-2,3-bis $(4-(\mathrm{N}, \mathrm{N}-$ bis((4-octyloxyl)phenyl)N-benzenamine-3-yl)phe-ny)quinoxaline (12)

According to a procedure similar to that for the synthesis of compound (11), compound (12) was obtained after reacting compound (5) with compound (10) in $84.4 \%$ yield as a deep yellow solid. ${ }^{1} \mathrm{H}$ NMR (400 $\mathrm{MHz}, \mathrm{CDCl}_{3}, \mathrm{TMS}, \delta_{\mathrm{ppm}}$ ): $7.90(\mathrm{~s}, 2 \mathrm{H}), 7.76(\mathrm{~d}, \mathrm{~J}=7.9 \mathrm{~Hz}, 4 \mathrm{H}), 7.56$ $(\mathrm{d}, \mathrm{J}=7.9 \mathrm{~Hz}, 4 \mathrm{H}), 7.45(\mathrm{~d}, \mathrm{~J}=8.0 \mathrm{~Hz}, 4 \mathrm{H})$, 7.34 to $0.34(\mathrm{~m}, 4 \mathrm{H}), 7.07(\mathrm{~d}, \mathrm{~J}=7.6 \mathrm{~Hz}, 4 \mathrm{H})$, $6.98(\mathrm{~d}, \mathrm{~J}=7.6 \mathrm{~Hz}, 4 \mathrm{H}), 6.83(\mathrm{~d}, \mathrm{~J}=8.4 \mathrm{~Hz}, 8 \mathrm{H})$, $6.72(\mathrm{~d}, \mathrm{~J}=3.5 \mathrm{~Hz}, 2 \mathrm{H}), 3.94(\mathrm{t}, \mathrm{J}=5.8 \mathrm{~Hz}, 8 \mathrm{H})$, 2.03 to $1.66(\mathrm{~m}, 8 \mathrm{H}), 1.52$ to $1.17(\mathrm{~m}, 40 \mathrm{H}), 0.88$ $(\mathrm{d}, \mathrm{J}=6.7 \mathrm{~Hz}, 12 \mathrm{H})$.

\section{Synthesis of ThQuTh}

ThQuTh was prepared according to a procedure similar to that for the synthesis of compound (11), using compound (6) and compound (3) as raw materials, ThQuTh was a deep red solid with a yield of $80.7 \%$. ${ }^{1} \mathrm{H}$ NMR $\left(400 \mathrm{MHz}, \mathrm{CDCl}_{3}\right.$, TMS, $\left.\delta_{\mathrm{ppm}}\right): 8.17(\mathrm{~s}, 2 \mathrm{H}), 7.92(\mathrm{~d}, \mathrm{~J}=8.0 \mathrm{~Hz}, 4 \mathrm{H})$, $7.84(\mathrm{~d}, \mathrm{~J}=3.1 \mathrm{~Hz}, 2 \mathrm{H}), 7.71(\mathrm{~d}, \mathrm{~J}=8.0 \mathrm{~Hz}, 4 \mathrm{H})$, $7.33(\mathrm{~d}, \mathrm{~J}=2.9 \mathrm{~Hz}, 2 \mathrm{H}), 6.98(\mathrm{~d}, \mathrm{~J}=4.8 \mathrm{~Hz}, 2 \mathrm{H})$, $6.88(\mathrm{~s}, 2 \mathrm{H}), 3.03(\mathrm{t}, \mathrm{J}=7.3 \mathrm{~Hz}, 4 \mathrm{H}), 2.95(\mathrm{t}, \mathrm{J}=$ $7.3 \mathrm{~Hz}, 4 \mathrm{H}), 1.99$ to $1.87(\mathrm{~m}, 4 \mathrm{H}), 1.84$ to 1.81 $(\mathrm{m}, 7.6 \mathrm{~Hz}, 8 \mathrm{H}), 1.58$ to $1.41(\mathrm{~m}, 40 \mathrm{H}), 1.01$ (s, $12 \mathrm{H}) \cdot{ }^{13} \mathrm{C}$ NMR $\left(100 \mathrm{MHz}, \mathrm{CDCl}_{3}, \mathrm{TMS}\right.$, $\left.\delta_{\mathrm{ppm}}\right): 150.73,149.15,146.48,141.03,137.34$, $137.19,136.39,135.34,131.16,130.99,126.60$, $126.47,125.20,125.08,123.96,123.33,53.36$, $31.93,31.87,30.33,29.46,29.35,29.26,29.21$, 22.67, 14.09. MS (MSD, m/z): $\mathrm{C}_{68} \mathrm{H}_{86} \mathrm{~N}_{2} \mathrm{~S}_{4}$, 1059.68; found, 1059.475

\section{Synthesis of $\mathrm{CzQuTh}$}

$\mathrm{CzQuTh}$ was prepared according to a procedure similar to that for the synthesis of compound (11) using compound (8) with compound (3) as raw 
materials; $\mathrm{CzQuTh}$ was a red solid with a yield of $87.4 \% .{ }^{1} \mathrm{H}$ NMR (400 MHz, $\mathrm{CDCl}_{3}, \mathrm{TMS}, \delta_{\mathrm{ppm}}$ ): $8.41(\mathrm{~s}, 2 \mathrm{H}), 8.16(\mathrm{~d}, \mathrm{~J}=7.6 \mathrm{~Hz}, 2 \mathrm{H}), 8.07(\mathrm{~s}$, $2 \mathrm{H}), 7.98(\mathrm{~d}, \mathrm{~J}=7.9 \mathrm{~Hz}, 4 \mathrm{H}), 7.86$ to $7.68(\mathrm{~m}$, $8 \mathrm{H}), 7.48$ to $7.41(\mathrm{~m}, 6 \mathrm{H}), 7.33$ to $7.15(\mathrm{~m}, 2 \mathrm{H})$, $6.88(\mathrm{~s}, 2 \mathrm{H}), 4.32(\mathrm{t}, \mathrm{J}=6.7 \mathrm{~Hz}, 4 \mathrm{H}), 2.93(\mathrm{t}, \mathrm{J}=$ $7.3 \mathrm{~Hz}, 4 \mathrm{H}), 1.89$ to $1.88(\mathrm{~m}, 4 \mathrm{H}), 1.82$ to 1.79 $(\mathrm{m}, 4 \mathrm{H}), 1.47$ to $1.24(\mathrm{~m}, 40 \mathrm{H}), 0.86(\mathrm{~s}, 12 \mathrm{H})$. ${ }^{13} \mathrm{C}$ NMR $\left(100 \mathrm{MHz}, \mathrm{CDCl}_{3}\right.$, TMS, $\left.\delta_{\mathrm{ppm}}\right): 151.23$, $149.15,142.59,140.95,140.22,137.22,137.00$, $136.50,131.42,131.08,126.93,126.55,126.49$, $125.85,125.10,124.02,123.47,123.04,120.51$, $119.00,118.92,109.00,108.90,43.26,31.98$, $31.84,31.73,30.34,29.76,29.72,29.54,29.42$, $29.34,29.33,29.22,29.05,27.37,22.73,22.65$, 14.16. MS (MSD, $\mathrm{m} / \mathrm{z}): \mathrm{C}_{84} \mathrm{H}_{96} \mathrm{~N}_{4} \mathrm{~S}_{2}, 1225.82$; found, 1226.656.

\section{Synthesis of $\mathrm{CzQuCz}$}

A mixture of compound (11) (0.10 g, $0.09 \mathrm{mmol})$, compound (7) (0.09 g, $0.22 \mathrm{mmol})$, $\mathrm{K}_{2} \mathrm{CO}_{3} \quad(11.87 \mathrm{mg}, \quad 0.09 \mathrm{mmol})$, THF/water (20 mL; 1:1 in volume), and $\mathrm{Pd}\left(\mathrm{PPh}_{3}\right)_{4}(2.98 \mathrm{mg}$, $0.0026 \mathrm{mmol}$ ) was carefully degassed and charged with nitrogen. The reaction mixture was heated to reflux for $24 \mathrm{~h}$. After cooling to room temperature, the mixture was extracted with chloroform three times. The combined organic phase was separated, washed with brine, dried over $\mathrm{MgSO}_{4}$, and distillated over the majority of solvent. The crude was purified by column chromatography using a mixture solvent of dichloromethane and petroleum ether (1:1) as eluent to afford the product as a dull purple solid (0.71 g, yield: $39.9 \%)$. ${ }^{1} \mathrm{H}$ NMR (400 MHz, $\left.\mathrm{CDCl}_{3}, \mathrm{TMS}, \delta_{\mathrm{ppm}}\right): 8.44$ (s, 4H), 8.11 (m, 8H), 7.99 to $7.72(\mathrm{~m}, 10 \mathrm{H}), 7.47$ to $7.41(\mathrm{~m}$, $12 \mathrm{H}), 7.24$ to $7.19(\mathrm{~m}, 6 \mathrm{H}), 7.08(\mathrm{~s}, 2 \mathrm{H}), 4.31(\mathrm{t}$, $\mathrm{J}=6.6 \mathrm{~Hz}, 8 \mathrm{H}), 1.89$ to $1.88(\mathrm{~m}, 8 \mathrm{H}), 1.39$ to 1.16 $(\mathrm{m}, 40 \mathrm{H}), 0.86$ to $0.79(\mathrm{~m}, 12 \mathrm{H}) .{ }^{13} \mathrm{C} \mathrm{NMR}$ $\left(100 \mathrm{MHz}, \mathrm{CDCl}_{3}, \mathrm{TMS}, \delta_{\mathrm{ppm}}\right): 140.91,140.18$, $131.41,126.76,125.75,125.21,123.45,123.06$, $120.68,118.92,109.02,108.79,53.47,43.21$, $31.85,31.83,29.75,29.45,29.41,29.23,29.05$, 27.37, 27.34, 22.65, 22.64, 14.11. MS ( MSD, $\mathrm{m} / \mathrm{z}$ ): $\mathrm{C}_{108} \mathrm{H}_{111} \mathrm{~N}_{6} \mathrm{~S}_{2}, 1556.2$; found, 1555.772 .

\section{Synthesis of TPAQuCz}

TPAQuCz was prepared according to a procedure similar to that for the synthesis of $\mathrm{CzQuCz}$ using compound (12) and compound (7) as raw materials, TPAQuCz was purplish red solid with a yield of $68 \%$. ${ }^{1} \mathrm{H} \mathrm{NMR}\left(400 \mathrm{MHz}, \mathrm{CDCl}_{3}\right.$, TMS, $\left.\delta_{\mathrm{ppm}}\right): 8.57(\mathrm{~s}, 2 \mathrm{H}), 8.26$ to $8.23(\mathrm{~m}, 4 \mathrm{H}), 8.10(\mathrm{~d}$, $\mathrm{J}=7.8 \mathrm{~Hz}, 4 \mathrm{H}), 8.02(\mathrm{~s}, 2 \mathrm{H}), 7.96(\mathrm{~d}, \mathrm{~J}=8.2 \mathrm{~Hz}$, $2 \mathrm{H}), 7.80(\mathrm{~d}, \mathrm{~J}=7.8 \mathrm{~Hz}, 4 \mathrm{H}), 7.65(\mathrm{~d}, \mathrm{~J}=8.2 \mathrm{~Hz}$, $4 \mathrm{H}), 7.55(\mathrm{t}, \mathrm{J}=7.7 \mathrm{~Hz}, 8 \mathrm{H}), 7.24(\mathrm{t}, \mathrm{J}=9.0 \mathrm{~Hz}$, $10 \mathrm{H}), 7.14(\mathrm{~d}, \mathrm{~J}=8.1 \mathrm{~Hz}, 4 \mathrm{H}), 6.98(\mathrm{~d}, \mathrm{~J}=8.4 \mathrm{~Hz}$, $8 \mathrm{H}), 4.30(\mathrm{t}, \mathrm{J}=6.6 \mathrm{~Hz}, 4 \mathrm{H}), 3.95(\mathrm{t}, \mathrm{J}=6.2 \mathrm{~Hz}$, $8 \mathrm{H}), 1.91$ to $1.75(\mathrm{~m}, 12 \mathrm{H}), 1.47(\mathrm{~m}, 60 \mathrm{H}), 0.86(\mathrm{~m}$, $18 \mathrm{H}) .{ }^{13} \mathrm{C} \mathrm{NMR}\left(100 \mathrm{MHz}, \mathrm{CDCl}_{3}\right.$, TMS, $\left.\delta_{\mathrm{ppm}}\right)$ : $155.59,148.55,148.43,140.88,140.71,139.96$, $136.94,136.76,132.04,131.32,127.55,126.70$, $126.05,125.95,125,78,123.64,123.28,122.94$, $121.37,120.76,120.50,119.07,115.35,108.95$, $108.87,53.46,43.19,31.90,31.84,29.46,29.42$, $29.32,29.23,29.05,27.36,26.28,22.73,22.65$, 14.17, 14.12. MS (MSD, m/z): $\mathrm{C}_{136} \mathrm{H}_{154} \mathrm{~N}_{6} \mathrm{O}_{4} \mathrm{~S}_{2}$, 2000.85; found, 2001.130.

\section{Results and discussion}

\subsection{Thermal stability}

The thermal properties of four SMs were evaluated with thermogravimetric analysis (TGA). The recorded TGA curves are shown in Fig. 3. The corresponding data are summarized in Table 1 . Decomposition temperatures $\mathrm{T}_{d}$ at $5 \%$ weight loss of ThQuTh, CzQuTh, CzQuCz and TPAQuCz are observed at $463,479,501$, and $451{ }^{\circ} \mathrm{C}$, respectively. The relatively high $\mathrm{T}_{\mathrm{d}}$ indicates that all the small molecules have good thermal stability and they are suitable for the fabrication of devices [34].

\subsection{Optical properties}

The normalized UV-Vis absorption spectra of the four small molecules in diluted $\mathrm{CHCl}_{3}$ solution are displayed in Fig. 4a, and the corresponding data are compiled in Table 1. All the compounds exhibit multiple absorption bands in the range of $250 \mathrm{~nm}$ to $650 \mathrm{~nm}$. In the range of $280 \mathrm{~nm}$ to $400 \mathrm{~nm}$, the high absorption intensity can be attributed to 
Table 1. Thermal, optical and electrochemical properties of ThQuTh, CzQuTh, CzQuCz and TPAQuCz.

\begin{tabular}{lcccccc}
\hline Compounds & $\mathrm{T}_{\mathrm{d}}$ & Solution & \multicolumn{2}{c}{ Film } & \multicolumn{2}{c}{ EHOHO $_{\text {ELUMO }}$} \\
& {$\left[{ }^{\circ} \mathrm{C}\right]$} & $\lambda_{\text {abs }}[\mathrm{nm}]$ & $\lambda_{\mathrm{abs}}[\mathrm{nm}]$ & $\mathrm{E}_{\mathrm{g}}^{\mathrm{opt}}[\mathrm{eV}]^{\mathrm{a}}$ & {$[\mathrm{eV}]$} & {$[\mathrm{eV}]^{\mathrm{b}}$} \\
\hline \hline ThQuTh & 463 & $314,345,430$ & 339,489 & 2.09 & -5.18 & -3.09 \\
CzQuTh & 479 & 302,418 & 358,429 & 2.01 & -5.02 & -3.01 \\
$\mathrm{CzQuCz}$ & 501 & $298,357,517$ & 367,540 & 1.77 & -4.97 & -3.20 \\
TPAQuCz & 451 & $290,360,521$ & 367,548 & 1.82 & -4.96 & -3.13 \\
\hline
\end{tabular}

${ }^{\mathrm{a}}$ Band gap estimated from optical absorption band edge of the film.

${ }^{\mathrm{b}} \mathrm{E}_{\mathrm{LUMO}}=-\left(\mathrm{E}_{\mathrm{HOMO}}+\mathrm{E}_{\mathrm{g}}^{\mathrm{opt}}\right)$.

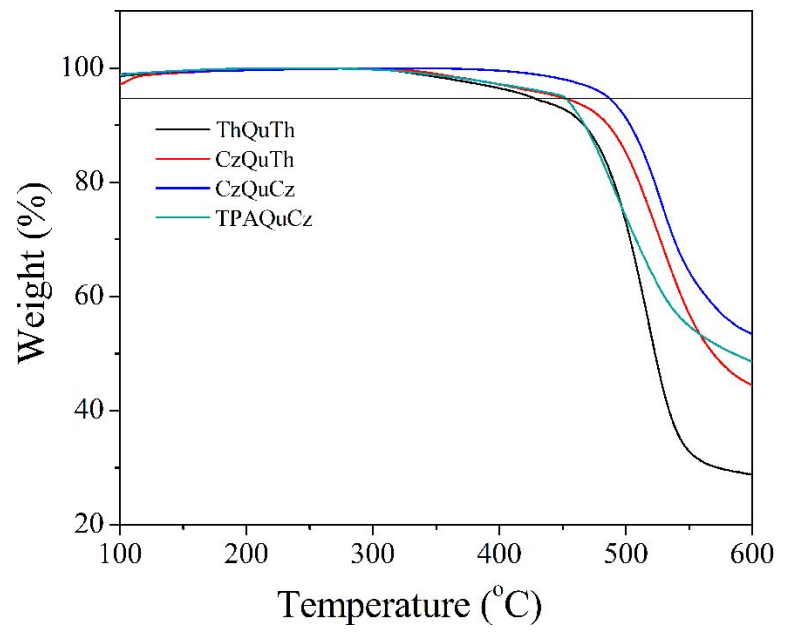

Fig. 3. TGA curves of ThQuTh, CzQuTh, CzQuCz and TPAQuCz.

$\pi \rightarrow \pi^{*}$ transition of molecular backbone, and the weaker broad band in the visible region $(400 \mathrm{~nm}$ to $650 \mathrm{~nm})$ to intramolecular charge transfer between the donor units and quinoxaline. The relative intensity of the former is significantly higher than that of the latter across the four molecules. There are variations probably caused by the donors attached to the quinoxaline core. Both $\mathrm{CzQuCz}$ and TPAQuCz exhibit extended absorption edges as compared ThQuTh and CzQuTh, showing that the electron-donating ability of TPA and $\mathrm{Cz}$ is stronger than that of Th. Consequently, the intramolecular charge transfer of $\mathrm{CzQuCz}$ and TPAQuCz is larger than that of ThQTh and CzQuTh [34]. Moreover, TPAQuCz exhibits higher absorption intensity than $\mathrm{CzQuCz}$, probably because the intramolecular charge transfer of TPA to quinoxaline core is stronger than that of $\mathrm{Cz}$ [35].
Fig. $4 \mathrm{~b}$ shows the optical absorption spectra of ThQuTh, CzQuTh, CzQuCz and TPAQuCz in thin films. They show absorption slightly shifted to longer wavelength in comparison with their counterparts in solution. Such distinct bathochromic shift is because the intermolecular interaction in solid state is stronger than that in liquid state [29]. The absorption edge of the films is at ca. $591 \mathrm{~nm}$, $616 \mathrm{~nm}, 700 \mathrm{~nm}$, and $681 \mathrm{~nm}$ for ThQuTh, $\mathrm{CzQuTh}, \mathrm{CzQuCz}$ and TPAQuCz, respectively, corresponding to band gaps of $2.09 \mathrm{eV}, 2.01 \mathrm{eV}$, $1.77 \mathrm{eV}$, and $1.82 \mathrm{eV}$. It is apparent that the attachment of TPA and $\mathrm{Cz}$ with strong electron-donating ability to the quinoxaline core can significantly lower the band gap.

\subsection{Electrochemical properties}

Cyclic voltammetry was performed to investigate the electrochemical properties and to estimate the HOMO and LUMO energy levels of ThQuTh, $\mathrm{CzQuTh}, \mathrm{CzQuCz}$ and TPAQuCz [36]. Fig. 5 shows the cyclic voltammograms of ThQuTh, $\mathrm{CzQuTh}, \mathrm{CzQuCz}$ and TPAQuCz films in the positive potential range, illustrating the $\mathrm{p}$-doping processes of the compounds. All the compounds exhibit an irreversible oxidation potential $\left(\mathrm{E}_{\mathrm{ox}}\right)$ at approximately $0.78 \mathrm{eV}, 0.62 \mathrm{eV}, 0.57 \mathrm{eV}$ and $0.56 \mathrm{~V}$ for ThQuTh, CzQuTh, $\mathrm{CzQuCz}$ and TPAQuCz, respectively (Table 1). However, no reduction of potentials $\left(\mathrm{E}_{\mathrm{red}}\right)$ has been detected. Therefore, the HOMO energy levels ( $\mathrm{E}_{\mathrm{HOMO}}$ ) have been calculated based on the empirical formula: $\mathrm{E}_{\text {HOMO }}=-\left(\mathrm{E}_{\mathrm{ox}}+4.80\right) \mathrm{eV}$ [37]. The LUMO energy levels ( $\mathrm{E}_{\mathrm{LUMO}}$ ) have to be estimated using the $\mathrm{E}_{\mathrm{HOMO}}$ and optical band gap $\left(\mathrm{E}_{\mathrm{g}}\right)$ values. 
(a)

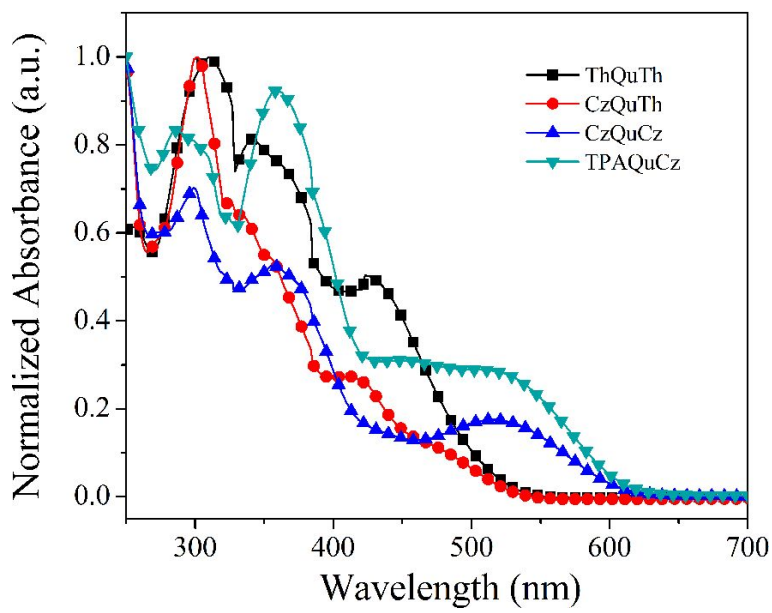

(b)

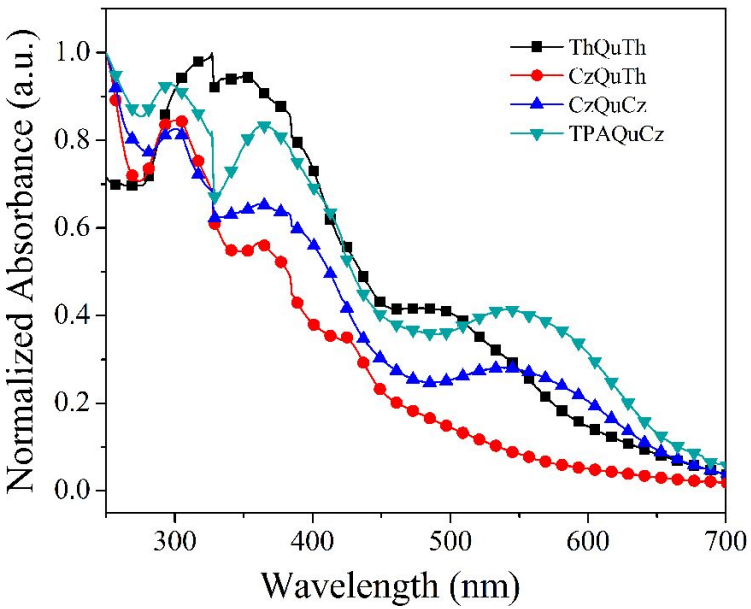

Fig. 4. UV-Vis spectra of ThQuTh, CzQuTh, CzQuCz and TPAQuCz (a) in chloroform; (b) in thin films.

In this aspect, $\mathrm{E}_{\mathrm{g}}$ was estimated to be about $2.09 \mathrm{eV}$, $2.01 \mathrm{eV}, 1.77 \mathrm{eV}$ and $1.82 \mathrm{eV}$ based on the UV-Vis absorption spectra of the corresponding films (Fig. 4b). The results of electrochemical measurements and calculated energy levels of the small molecules are listed in Table 1.

From Table 1, it is clear that the HOMO levels of ThQTh (-5.18 eV), CzQTh (-5.02 eV), CzQCz $(-4.97 \mathrm{eV})$ and TPAQuCz $(-4.96 \mathrm{eV})$ gradually increase, corresponding to the increase of electrondonating abilities of the donor units in these D-A type small molecules [34]. It can be seen that the LUMO levels of ThQuTh $(-3.09 \mathrm{eV}), \mathrm{CzQuTh}$ $(-3.01 \mathrm{eV}), \mathrm{CzQuCz}(-3.20 \mathrm{eV})$ and TPAQuCz $(-3.13 \mathrm{eV})$ show a trend of gradually decreasing. It is apparent that the LUMO energy levels can be tuned by adjusting the electron-donating capacity of the moieties conjugated to quinoxaline. Furthermore, the relatively low LUMO energy levels of the four small molecules could be attributed the strong reduction capacity of the quinoxaline acceptor unit.

\subsection{Photovoltaic performance}

To investigate the photovoltaic properties of ThQuTh, CzQuTh, $\mathrm{CzQuCz}$ and $\mathrm{TPAQuCz}$ as an electron donor in BHJ-OSCs, photovoltaic devices were fabricated with a layer structure of ITO/PEDOT:PSS/small

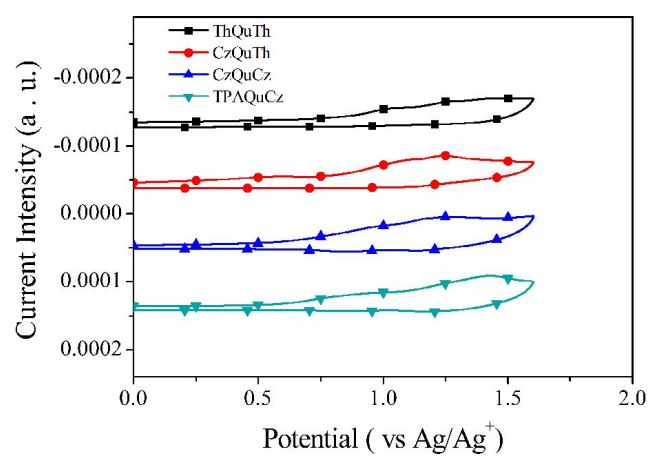

Fig. 5. CV curves of ThQuTh, CzQuTh, $\mathrm{CzQuCz}$ and TPAQuCz.

molecules: $\mathrm{PC}_{61} \mathrm{BM} / \mathrm{LiF} / \mathrm{Al}$. The J-V characteristics of the cells measured under the illumination of AM $1.5 \mathrm{G}\left(100 \mathrm{~mW} \cdot \mathrm{m}^{-2}\right)$ from a solar simulator are shown in Fig. 6, and the photovoltaic performances of the devices are summarized in Table 2. It is shown that the PCEs rise from $0.05 \%$ to $0.37 \%$ for the devices that are based on ThQuTh, CzQuTh, CzQuCz and TPAQuCz. From Table 2, it is clear that the $\mathrm{J}_{\mathrm{sc}}$ and FF of the ThQuTh-, CzQuTh-, CzQuCz- and TPAQuCz -based BHJ-OSCs gradually increase together with the increase of electron-donating ability of the D moieties. However, the $\mathrm{J}_{\mathrm{sc}}$ of the TPAQuCz-based device is $1.91 \mathrm{~mA} / \mathrm{cm}^{2}$, which is lower than that of the $\mathrm{CzQuCz}$-based device. The phenomenon may be attributed to the difference in charge transport 
Table 2. Photovoltaic parameters of ThQuTh, CzQuTh, CzQuCz and TPAQuCz bsed solar cells.

\begin{tabular}{lccccc}
\hline \multicolumn{1}{c}{ SMs } & D/A ratio & $\mathrm{V}_{\mathrm{oc}}[\mathrm{V}]$ & $\mathrm{J}_{\mathrm{sc}}{ }^{\mathrm{a}}\left[\mathrm{mA} \cdot \mathrm{cm}^{-2}\right]$ & FF [\%] & PCE [\%] \\
\hline \hline ThQuTh & $1: 3$ & 0.47 & 0.47 & 22.6 & 0.05 \\
CzQuTh, & $1: 3$ & 0.59 & 0.89 & 22.9 & 0.12 \\
CzQuCz & $1: 3$ & 0.47 & 2.24 & 23.7 & 0.25 \\
TPAQuCz & $1: 3$ & 0.68 & 1.91 & 28.0 & 0.37 \\
\hline
\end{tabular}

abilities from the D units to the quinoxaline core. The $\mathrm{V}_{\mathrm{oc}}$ is related to the difference between the LUMO energy level of the acceptor and the HOMO energy level of the donor within the active layer. Thus, the fact that the device based on $\mathrm{CzQuTh}: \mathrm{PC}_{61} \mathrm{BM}$ has higher $\mathrm{V}_{\mathrm{oc}}(0.59 \mathrm{~V})$ comparing with that based on ThQuTh: $\mathrm{PC}_{60} \mathrm{BM}$ $\left(\mathrm{V}_{\mathrm{oc}}=0.47 \mathrm{~V}\right)$ could be explained by the HOMO energy level of CzQTh $(-5.02 \mathrm{eV})$ as compared to that of ThQuTh $(-5.18 \mathrm{eV})$. However, from Table 2, it is clear that despite $\mathrm{CzQuCz}$ has higher $\mathrm{E}_{\mathrm{HOMO}}$, the TPAQuCz:PC${ }_{61} \mathrm{BM}$ device has higher $\mathrm{V}_{\mathrm{oc}}(0.68 \mathrm{~V})$ than the $\mathrm{CzQuCz}: \mathrm{PC}_{61} \mathrm{BM}$ $\left(\mathrm{V}_{\mathrm{oc}}=0.47 \mathrm{~V}\right)$. The lower $\mathrm{V}_{\mathrm{oc}}$ of the latter can be due to the relatively poor dispersibility of $\mathrm{CzQuCz}$ in the $\mathrm{PC}_{61} \mathrm{BM}$ matrix.

Furthermore, the efficiency of power conversion of the TPAQuCz:PC ${ }_{61} \mathrm{BM}$ device is the highest $(0.37 \%)$, showing a $\mathrm{V}_{\mathrm{oc}}$ of $0.68 \mathrm{~V}$, a $\mathrm{J}_{\mathrm{sc}}$ of $1.91 \mathrm{~mA} / \mathrm{cm}^{2}$ and a FF of 0.28 , higher than that of $\mathrm{CzQuCz}: \mathrm{PC}_{61} \mathrm{BM}$. This could be due to the stronger absorption intensity of TPAQuCz in comparison with $\mathrm{CzQuCz}$. Also, the efficiency for power conversion of the $\mathrm{CzQuCz}: \mathrm{PC}_{61} \mathrm{BM}$ device $(0.25 \%)$ is higher than that of $\mathrm{CzQuTh}: \mathrm{PC}_{61} \mathrm{BM}$ $(0.12 \%)$ and ThQuTh:PC ${ }_{61} \mathrm{BM}(0.05 \%)$. Clearly the gradual replacement of $\mathrm{Cz}$, a strong donor, with Th, a weak donor, results in the decline of efficiency. Hence, the power conversion efficiency of this kind of BHJ-OSCs is dependent on the electron-donating ability as well as the absorption intensity of the SMSs.

\section{Conclusions}

Benzo-quinoxaline derivatives with low band gap are apt for electron injection and transport. The four small molecules of star shape

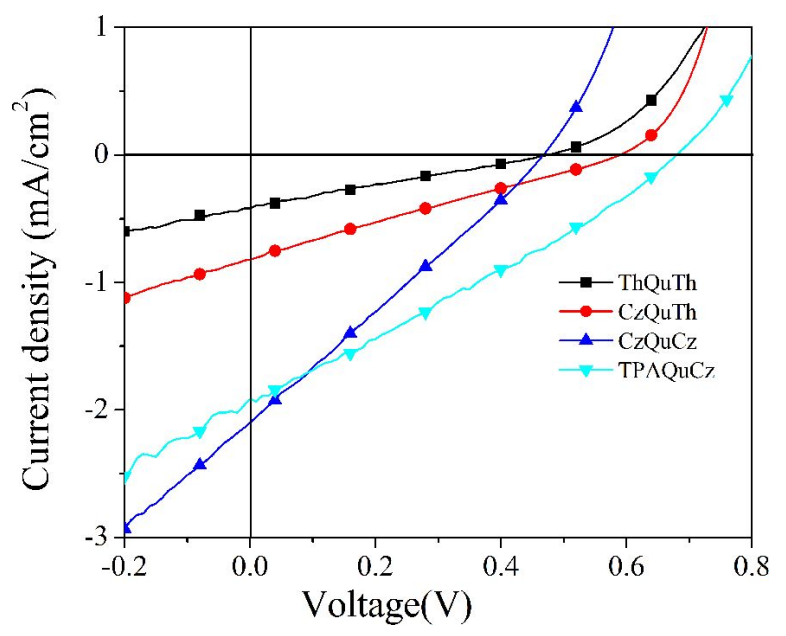

Fig. 6. J-V curves of ThQuTh, CzQuTh, $\mathrm{CzQuCz}$ and TPAQuCz based solar cells.

having electron-deficient benzo-quinoxaline core were synthesized and characterized. The films made of the SMs display morphology that indicates good dispersibility of the small molecules. Optical and electrochemical data reveal that the replacement of a weak donor Th with a strong donor $\mathrm{Cz}$ leads to an obvious increase of HOMO level and an even larger increase of LUMO level, resulting in band-gap contraction. The use of TPAQuCz instead of $\mathrm{CzQuCz}$ in BHJ-OSCs devices leads to oxidation potential similar to that in solution but results in higher efficiency of power conversion, plausibly due to the stronger absorption intensity of TPAQuCz. Also, the PCEs increase with the rise of electron-donating ability of the $\mathrm{D}$ units, indicates that the small molecules with a benzo-quinoxaline core can be modified for improved solar cell performance. With careful design, this class of SMs could be promising organic photovoltaic materials for the development of solar cells. 


\section{Acknowledgements}

This work was supported by a Grant from the National Natural Science Foundation of China (Grant No. 21207034) and a Grant from the Natural Science Foundation of Hunan Province (Grant No. 2015JJ2042). The authors also express their thanks to Prof. C.T. Au for polishing the English writing of the paper.

\section{References}

[1] Jin Y., Chen Z., Dong S., Zheng N., Ying L., Jiang X.F., LiU F., Huang F., CaO Y., Adv. Mater., 28 (2016), 9811.

[2] LeE J., Sin D.H., Moon B., Shin J., KiM H.G., KIM M., CHo K., Energ. Environ. Sci., 10 (2017), 247

[3] Ro H.W., Downing J.M., Engmann S., HerzING A.A., Delongchamp D.M., Richter L.J., Mukherjee S., Ade H., Abdelsamie M., JAGadAMMA L.K., AMASSIAN A., LiU Y., YAN H., Solar Cell. Energy Environ. Sci., 9 (2016), 2835

[4] Zhang B., Liang J.F., Hu L.W., Peng F., Chen G.T., YANG W., J Mater Sci., 16 (2015), 5609.

[5] Liu Y., Zhao J., Li Z., Mu C., Ma W., Hu H., JiAng K., Lin H., Ade H., YAN H., Nat. Commun., 5 (2014), 5293.

[6] Li Y., Yue G.T., Chen X.X., He B.L., Chu L., Chen H.Y., Wu J.H., TANG Q.W., J Mater Sci., 9 (2013), 3528.

[7] Zheng Z., Zhang S., Zhang J., QIN Y., Li W., Yu R., Wei Z., Hou J., Adv. Mater., 28 (2016), 5133.

[8] Qiao F., LiU A.M., Hu Z.Q., LiU Y.T., Yu S.W., ZHOU Z.G., J. Mater. Sci., 13 (2009), 3462.

[9] ZhaO J., Li Y., YANG G., JiANG K., LiN H., ADE H., Ma W., Yan H., Nat. Energy, 1 (2016), 15027.

[10] Zhao G.J., Wu G.L., He C., Bai F.Q., XI H.X., Zhang H.X., Li Y.F., J. Phys. Chem., 113 (2009), 2636.

[11] Wu G., Zhao G., He C., Zhang J., He Q., Chen X., LI Y., Sol. Energ. Mater. Sol. C., 93 (2009), 108.

[12] Lin Y., Li Y., Zhan X., Chem. Soc. Rev., 41 (2012), 4245.

[13] Mishra A., Bauerle P., Ang. Chem., 51 (2012), 2020.

[14] Coughlin J., Henson Z., Welch G., BaZan G., Chem. Res., 47 (2014), 257.

[15] Chen Y., Wang X., Long G., Acc. Chem. Res., 46 (2013), 2645.

[16] Wang D., Ding W., Geng Z., Wang L., Geng Y., Su Z., YU H., Mater. Chem. Phys., 145 (2014), 387.

[17] KaN B., Li M., Zhang Q., LiU F., WAN X., Wang Y., Ni W., Long G., Yang X., Feng H., Zuo Y., Zhang M., Huang F., CaO Y., Russell T.P., ChEn Y.A., J. Am. Chem. Soc., 137 (2015), 3886.

[18] Shi Q., Cheng P., Li Y., Zhan X., Adv. Energ. Mater., 2(2012), 63.

[19] Lincker F., Delbosc N., Bailly S., De BettigNies R., Billon M., Pron A., Demadrille R., $A d v$. Funct. Mater., 18 (2008), 3444.
[20] Zhang J., Yang Y., He C., He Y., Zhao G., Li Y., Macromolecules, 42 (2009), 7619.

[21] Yang Y., Zhang J., Zhou Y., Zhao G., He C., Li Y., Andersson M., Inganas O., Zhang F., J. Phys. Chem. C, 114 (2010), 3701.

[22] Zheng Z., Awartani O.M., Gautam B., LiU D., QiN Y., LI W., Bataller A., Gundogdu K., Ade H., Hou J., Adv. Mater., 5 (2016), 29.

[23] Fan Q., Xiao M., LiU Y., Su W., Gao H., Tan H., Wang Y., Lei G., Yang R., Zhu W., Polym. Chem., 6 (2015), 4290.

[24] Su W., Xiao M., Fan Q., Zhong J., Chen J., Dang D., Shi J., Xiong W., Duan X., Tan H., LIU Y., ZHU W., Org. Electron., 17 (2015), 129.

[25] Fan Q., Liu Y., Xiao M., Su W., Gao H., Chen J., TAN H., Wang Y., YAng R., ZHU W., J. Mater. Chem. C, 3 (2015), 6240.

[26] Lee D.-C., Brownell V.L., Yan L., You W., ACS Appl. Mater. Interfaces, 6 (2014), 15767.

[27] Chang D. W., Ko S.-J., Kim J.Y., DAi L., BAEK J.-B., Synth. Met., 162 (2012), 1169.

[28] Li W., Wang D., Wang S., Ma W., Hedstroem S., James D. I., Xu X., Persson P., Fabiano S., Berggren M., Inganaes O., Huang F., Wang E., ACS Appl. Mater. Inter., 7 (2015), 27106.

[29] Velusamy M., Huang J.H., Hsu Y.C., Chou H.H., Ho K.C., WU P.L., Chang W.H., LIN J.T., Chu C.W., Org. Lett., 11 (2009), 4989.

[30] Hagemann O., Jørgensen M., Krebs F.C., J. Org. Chem., 71 (2006), 5546.

[31] Lim B., BAeg K.J., Jeong H.G., Jo J., Kim H., PARK J.W., NOH Y.Y., VAK D., PARK J.H., PARK J.W., Kim D.Y., Adv. Mater, 21 (2009), 2808.

[32] Svensson M., Zhang F., Veenstra S.C., Verhees W.J.H., Hummelen J.C., Kroon J.M., INGANAS O., Adv. Mater, 15 (2003), 988.

[33] Xu M.F., Li R.Z., Pootrakulchote N., Shi D., GuO J., Yi Z.H., ZAKeERUddin S.M., GRATZEL M., WANG P., J. Phys. Chem., 112 (2008), 19770. b) LiU M., WANG Y.F., ZhaNG Z.Y., Li J.M., LiU Y., TAN H., Ni M.J., LEI G.T., ZHU M.X., ZHU W.G., J. Polym. Sci. Pol. Chem., 49 (2011), 3874.

[34] Li Z., Dong Q., Xu B., Li H., Wen S., Pei J., Yao S., Lu H., Li P., Tian W., Sol. Energ. Mater. Sol. C., 95 (2011), 2272.

[35] Zhang W.F., NG G.M., TaM H.L., Wong M.S., Zhu F.S., J. Poly. Sci. Part A: Poly. Chem., 49 (2011), 1865.

[36] So S., Choi H., Kim C., Cho N., Ko H.M., LeE J.K., Ko J., Sol. Energ. Mater. Sol. C, 95 (2011), 3433.

[37] Li Y.F., CaO Y., GaO J., Wang D.L., YU G., HeEger A.J., Synth. Met., 99 (1999), 243. 